\title{
Multilingual interaction in chat rooms: translanguaging to learn and learning to translanguage
}

\section{Sílvia Melo-Pfeifer \& Maria Helena de Araújo e Sá}

To cite this article: Sílvia Melo-Pfeifer \& Maria Helena de Araújo e Sá (2018): Multilingual interaction in chat rooms: translanguaging to learn and learning to translanguage, International Journal of Bilingual Education and Bilingualism, DOI: 10.1080/13670050.2018.1452895

To link to this article: https://doi.org/10.1080/13670050.2018.1452895

曲 Published online: 20 Mar 2018.

Submit your article to this journal $₫$

Q View related articles $\longleftarrow$

View Crossmark data $\complement$ 


\title{
Multilingual interaction in chat rooms: translanguaging to learn and learning to translanguage
}

\author{
Sílvia Melo-Pfeifer ${ }^{a}$ and Maria Helena de Araújo e Sáb

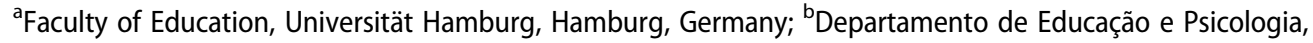 \\ Universidade de Aveiro, Aveiro, Portugal
}

\begin{abstract}
In this chapter, we analyse the co-construction of meaning by university students in romance language (RL) chat rooms, in an online platform focused on multilingual language practice and learning. This communicative situation can best be described through the concept of 'intercomprehension', i.e. a multilingual and multisemiotic communicative practice between speakers of different languages (in this case, typologically related languages), and will be analysed using a translanguaging lens, which is embedded in a heteroglossic perspective. Such an analysis invites us to perceive fluidity in the borders between languages and inside individuals' repertoires. In this particular multilingual learning situation, where participants communicate to learn and learn to communicate in $\mathrm{RL}$ chat rooms, we will observe speakers' double orientation towards translanguaging, i.e. the interconnection between 'translanguaging to learn' and 'learning to translanguage'. The results demonstrate a strategic use of translanguaging skills (with specific affective, cognitive and social goals), together with the subjects' explicit agency when engaged in intercomprehensive communicative practices.
\end{abstract}

\section{ARTICLE HISTORY}

Received 15 February 2018

Accepted 7 March 2018

\section{KEYWORDS}

Intercomprehension;

heteroglossia;

translanguaging; multilingual interaction; chat rooms

\section{Introduction}

There is a long tradition in foreign language education that sees interaction as a locus of cognitive, social and emotional engagement leading to language acquisition (Gajo and Mondada 2000; Matthey 1996; Porquier 1994; Vasseur 2005). In recent years, several concepts have been used to deal with interactions that make use of more than one language, namely languages of the same linguistic family, such as 'lingua receptiva' (Ten Thije 2013, 2014; Ten Thije and Zeevaert 2007), 'receptive multilingualism' (Braunmüller and Zeevaert 2001), 'interproduction' (Capucho 2011, 2012; see also Capucho et al in this special issue) and 'intercomprehension' (Degache 2006; Doyé 2005). In this paper, we have chosen the concept intercomprehension due to its wide use within multilingual approaches to teacher education and language education and in studies referring to plurilingual online interaction within educational fields, our research context. However, because the research framework on intercomprehension, even if it favours a multilingual posture, still privileges a monoglossic stance (García and Wei 2014; also Bailey 2011), we will adopt a 'translanguaging lens' to grasp the complexity of multilingual interaction between Romance Languages (RLs) in chat rooms, where languages beyond the RL family, and other semiotic resources, are combined to accomplish meaning and foster multiple language acquisition. 
Translanguaging has been defined as pedagogy, practice, strategy and skill (Canagarajah 2011; Creese and Blackledge 2010; García 2014; García and Wei 2014; Hornberger and Link 2012; Lewis, Jones, and Baker 2012; Palmer et al. 2014), and placed within the scope of a heteroglossic perspective that understands interceptions between linguistic borders, as well as between linguistic and non-linguistic resources, as potentially creative and empowering language/languaging learning practices. In this contribution, we address translanguaging as a skill, i.e. as the ability to make use of multiple semiotic resources in order to co-construct meaning (García and Wei 2014), in chat conversations where multiple RLs (Catalan, French, Italian, Portuguese and Spanish) share the discursive floor. Thus, we see translanguaging as originating new and complex practices and meanings (García, Flores, and Woodley 2012) and referring to the collaborative accomplishment of multilingual 'justin-time-doing'. While analysing our interactional samples, we will look at languages as practices and not merely as structures, as something speakers collaboratively achieve, rather than as systems they draw on and use (adapted from Pennycook 2010, 2). The focus will thus be on meaning-making through linguistic (and non-linguistic) resources and not on languages taken in isolation and added to one another during the process.

The data were collected in the scope of the European Galanet ${ }^{1}$ project (which originated a platform for intercomprehension in RL; see the methodological section). The communicative contract in this platform is explicitly multilingual, stressing that participants (students and tutors) should use their own RL and understand the RL of the other interlocutors (the project engaged universities and secondary schools of different countries). Even if this communicative contract challenges a monolingual orientation to communication (Canagarajah 2013), some monoglossic tendencies may still be identified: first, in the common definition of Intercomprehension (IC), some languages are said to be used productively ('to speak one language') and others receptively ('understand the language of the others'); second, at the beginning of each session, the platform asks the participants to classify their languages in terms of 'reference' (to be used productively) and 'target' RL (the RL in which receptive skills are to be developed); third, RLs are separated from other linguistic families, even those speakers bring through their repertoires.

In fact, some initial studies of this communicative format (related to the development of intercomprehension from an interactional perspective) show that students often do not abide by this monoglossic contract and use all the linguistic resources they possess, or are acquiring, during the interaction (knowledge of $\mathrm{RL}$ as well as languages from other linguistic families, Bono and MeloPfeifer 2011). This means that the chat room communication under study could be called a 'multipluri' linguistic setting (Ehrhart 2010), crossing the communicative contract's multilingualism with the participants' own plurilingualism.

It is important to recognize intercomprehension in online settings as a communicative practice where 'more than one identifiable set of linguistic resources is in use and in play simultaneously' (Blackledge and Creese 2014, 11), but combined with other semiotic resources as well. Indeed, because of certain characteristics of chat conversations (Crystal 2011), e.g. their pragmatic minimalism, other 'sense-makers' and 'sense-containers' (Jewitt 2009) such as smileys or the expressive use of punctuation and capital letters are mobilized to create, support and/or increase the meaning of the verbal utterances. This use configures intercomprehension in multilingual chat conversations as plurisemiotic, as it integrates multiple languages and other semiotic resources.

Following these lines, our contribution will look at intercomprehension from a heteroglossic stance, enriched by a translanguaging point of view, as multilingual repertoires and languages are perceived more fluidly; and reinforce the multimodal dimension in approaches towards intercomprehension and translanguaging, which are still predominantly language-centred despite groundbreaking work pointing to their multimodality and trans-semioticity:

Today new technologies have enabled the production of more fluid language texts [ ... ]. Digital genres such as emails [ ... ], online discussion forums, blogging [ ... ] and instant messaging [ ... ] have brought translanguaging in multimodal writing to the forefront (García and Wei 2014, 27). 
In this paper, we will show participants' double orientation towards translanguaging in a pedagogical context (foreign language learning in multilingual chat rooms): translanguaging to learn and learning to translanguage. Through a conversation analysis of two interactional excerpts, we will answer the following research questions:

- How do students participating in these chat rooms (multi/plurilingual and oriented toward the development of intercomprehension among speakers of different $\mathrm{RL}$ ) use translanguaging skills to learn about the different RL being used in the interaction?

- How do students learn to translanguage in order to gain the communicative abilities needed for engaging in such multilingual scenarios?

- How are these two orientations, 'translanguaging to learn' and 'learning to translanguage', interconnected, and how can we transpose them into more formal pedagogic scenarios?

\section{Multilingual education: intercomprehension and translanguaging}

As linguistic borders are perceived as blurring and linguistic cross-fertilization as a pervasive phenomenon, any attempt at teaching and learning ONE language should be acknowledged as a comfortable misconception. Indeed, diversity is constitutive of each language and consequently transversal to any context of foreign language learning. Therefore, language education always and inevitably engages with diversity and plurality, leading to a holistic comprehension of the world's linguistic ecology, i.e. linguistic organization, management, manipulation and dispensation (Aronin and Singleton 2008, 2012).

In the scope of multilingual education, several pluralistic approaches to teaching and learning were developed in Europe in the past 30 years: the intercultural approach, intercomprehension, awakening to languages and integrated didactics (Candelier et al. 2012). These perspectives challenge the monolingual classroom and monolingual pedagogic practices, including several linguistic and cultural varieties as objects of attention in foreign language education:

\footnotetext{
The term 'pluralistic approaches to languages and cultures' refers to didactic approaches that use teaching/learning activities involving several (i.e. more than one) varieties of languages or cultures. This is to be contrasted with approaches that might be called 'singular', in which the didactic approach takes account of only one language or a particular culture, and deals with it in isolation. Singular approaches of this kind were particularly valued when structural and, later, 'communicative' methods were developed and all translation and recourse to the first language were banished from the teaching process. (Candelier et al. 2012, 6, emphasis in the original)
}

In this contribution, we specifically deal with intercomprehension, a pluralistic approach that has so far been mainly concerned with the study of multilingual oral and written comprehension processing and development (multilingual reception) (Doyé 2005; Doyé and Meissner 2010). In these studies, intercomprehension was seen as the ability to understand oral or written texts in a language of the same family as the speaker's L1 or other previous learnt languages, without any previous formal instruction in that language. Research in this field tries, on the one hand, to understand the linguistic, cognitive, psycholinguistic and emotional specificities of the speaker/learner that favour access to the meaning in a (neighbour) language, and, on the other hand, to identify textual particularities (even beyond linguistic traits) that facilitate written and oral comprehension. From an educational perspective, intercomprehension posits that it is possible to decouple competences and start the learning path by developing comprehension skills, as it is expected that a focus on linguistic transparency will increase students' motivation and support the acquisition of production skills, in terms of time and effort expended (Bär 2009). Within this framework, foreign language education, particularly in typologically related languages, capitalizes on the possibilities of a 'transfer didactics' (Meißner 2004).

Despite the fact that this is the most dominant perspective across research work dealing with intercomprehension in RL (and even beyond), another perspective is garnering attention because 
of European research groups focused on multilingual interaction within a given linguistic family (Araújo e Sá and Melo-Pfeifer 2010; Capucho 2012). Indeed, intercomprehension is a pluralistic approach with high potential for understanding multilingual interaction and the co-construction of meaning in communicative situations where several languages, particularly of the same linguistic family, are allowed and activated as sense-making tools. From this interactional perspective, intercomprehension is challenging the idea that communication must occur in only one language or that a shared common language is a necessary precondition to communication. From this angle, the mainstream definition of intercomprehension stresses that a speaker uses the RL he/she knows and understands the one(s) of their interlocutor(s). Nonetheless, as some studies have pointed out, this communicative practice is far more complex than that, as intercomprehension allows and even promotes the co-presence of several languages belonging or not to a linguistic continuum - in our case the RL continuum. From this perspective, the so-called Swiss model also illustrates communicative situations where everyone speaks their language and understands the language of the interlocutor, despite the fact that those languages belong to different linguistic families (Lüdi 2007). Intercomprehension, as a 'fluid language practice' (García and Leiva 2014, 200), allows speakers to multilingually co-construct meaning and share their multilingual competences (Melo-Pfeifer 2015), by simultaneously adopting and developing productive and receptive strategies.

Some specificities of intercomprehension between $\mathrm{RL}$ speakers have already been presented and discussed elsewhere (Araújo e Sá, de Carlo, and Melo-Pfeifer 2010; Araújo e Sá and Melo 2007; MeloPfeifer 2015). Following this multilingual communicative orientation, we may say that all RL are part of a linguistic continuum and communicative practices using them are heteroglossic per se, as they are intertwined and carry multiple signs from each other; thus, from the moment one is able to speak or understand one RL, one can communicate across linguistic borders. Again, this linguistic continuum allows interlocutors to engage in conversations where they share different compounds of the linguistic richness available, and where very few communication problems occur, namely those arising from linguistic opacity (Araújo e Sá and Melo 2003; Vela Delfa 2009). When such communicative clashes occur, problems are usually solved using the multilingual resources at the speakers' disposal, offering specific occasions for the development of language awareness and multilingual learning (Araújo e Sá and Melo 2007; Carpi and De Carlo 2009). Intercomprehension thus is a result of emotional, cognitive and strategic involvement in the co-construction of sense, made possible by speakers' collaborative work (namely through the active sharing of resources) and the characteristics of the semiotic resources (specifically the partial and potential transparency of the languages being used), which allows for the production of 'hybrid utterances' (Lüdi, Höchle, and Yanaprasart 2013).

However, as stated above, multilingual communication in $\mathrm{RL}$ - when described through the concept of intercomprehension - is, despite the recent renewal that comes across through new terminological proposals like 'interproduction' (Capucho 2011), predominantly understood within a monoglossic framework. Indeed, in most communicative settings, the communicative contract keeps the languages used in interaction separate, some to be used productively ('to speak the Romance language one knows') and others targeted as comprehension outcomes ('to understand the Romance languages of the others').

The production and reception clauses included in the communicative agreement of the intercomprehension sessions in Galanet are, however, frequently challenged by speakers engaged in those complex situations: first, our analysis of $\mathrm{RL}$ chat rooms in higher education contexts revealed that students use different languages as remediation or mediation tools (Melo-Pfeifer 2014), as instruments of humour and play, and as an identity marker; second, the students sometimes do not limit themselves to the use of the RL identified as 'reference language', as they actively engage in the production of utterances in other RL (Melo-Pfeifer 2015), in order to immediately acquire further means of participating in the multilingual communication.

Because of these two observable violations of the communicative contract in these very specific situations, we claimed that studies on intercomprehension in an interactional perspective that 
impose a monoglossic communicative contract should embrace a more heteroglossic perspective. Instead, they could suggest a communicative contract that breaks linguistic constraints, like the language distribution according to productive and receptive skills, or the mere juxtaposition of RL (Melo-Pfeifer 2016). A heteroglossic perspective acknowledges that in RL communication, interlocutors implement creative and supplementary strategies (like resorting to other languages) to engage with each other, to negotiate intelligibility and to collaboratively achieve social meaning by crossing languages and voices. This perspective also recognizes that performing multilingual RL communication engages interlocutors in the co-construction of context, community solidarity and linguistic well-being. Furthermore, the so-called productive and receptive skills in $\mathrm{RL}$ can be deployed across several linguistic resources at the same time, which was grasped in the concept of 'transcodic formulation' and 'plurilingual speech' (Lüdi and Py 1986), and even this dual division between receptive and productive abilities can be challenged, as the production is oriented to the reception and vice versa, what Araújo e Sá (1996) called 'antecipação diligente' ('diligent anticipation'). More heteroglossic communicative contracts would allow the development of new and more adapted communicative scenarios in pedagogic settings.

Finally, it should be recognized that intercomprehension between RL relies on much more than words and its analysis should not be biased by or restricted to a linguistic perspective (still prevalent) placing linguistic opacity or transparency per se at the heart of comprehension or misunderstanding. Instead, the co-construction of meaning in multilingual interaction involves and depends on context and scenario, and on several semiotic resources, such as gestures, gazes, paces, signs and symbols. In multilingual chat rooms, like the ones we will analyse in this contribution, non-linguistic sense-makers and sense-containers are introduced (smileys, capital letters, repetitions, effusive punctuation, ...), making intercomprehension in this context a semiotically complex practice. The perception of this complexity and trans-semioticity can best be grasped through a concept such as translanguaging (García and Wei 2014), as it refers to trans-semiotic communicative practices that criss-cross several linguistic resources (or 'bits of languages', according to Blommaert 2010) and other semiotic codes. This articulated and complementary use of codes and the multisemioticity attached to the concept of translanguaging led us to prefer the concept of translanguaging to the one of 'codeswitching', which is still commonly associated to the use of languages as isolated entities and used to approach interaction with a predominantly linguistic focus.

This more heteroglossic perspective of intercomprehension between $\mathrm{RL}$, which gains in complexity by being grasped through the concept of translanguaging, justifies our double research perspective, already present in Lüdi (2003): (1) translanguaging to learn: students engage in interactional sequences in order to expand their multilingual resources; (2) learning to translanguage: they use their multilingual resources to co-construct a multilingual norm more able to fully address the skills and wishes of the multilingual self and its interlocutors.

\section{The empirical study}

The interactions studied in this contribution ${ }^{2}$ were collected from an online platform designed to develop intercomprehension between individuals, usually university students, who master one or more RL.

The Galanet platform privileged a telecollaborative work, based on several working spaces and communicative tools, in order to accomplish a collective task. Thus, it includes synchronic (chat) and asynchronic (discussion forum and e-mail) communicational tools, through which students from RL countries and/or engaged in learning a RL interact to develop a multilingual and collaborative project: a Press Dossier on a certain theme (for example on 'Ridiamo per le stesse cose? ... Y a-t-il un humour romanophone?' / 'Do we laugh at the same things?... Is there a Romance Languages humour?', the theme of the session analysed here) (see Araújo e Sá, de Carlo, and Melo-Pfeifer 2010 for more details). The different communicative spaces of the platform can be seen in the centre of Figure 1, a print screen of the platform, including: (a) discussions forums (the 'amphitheatre', 


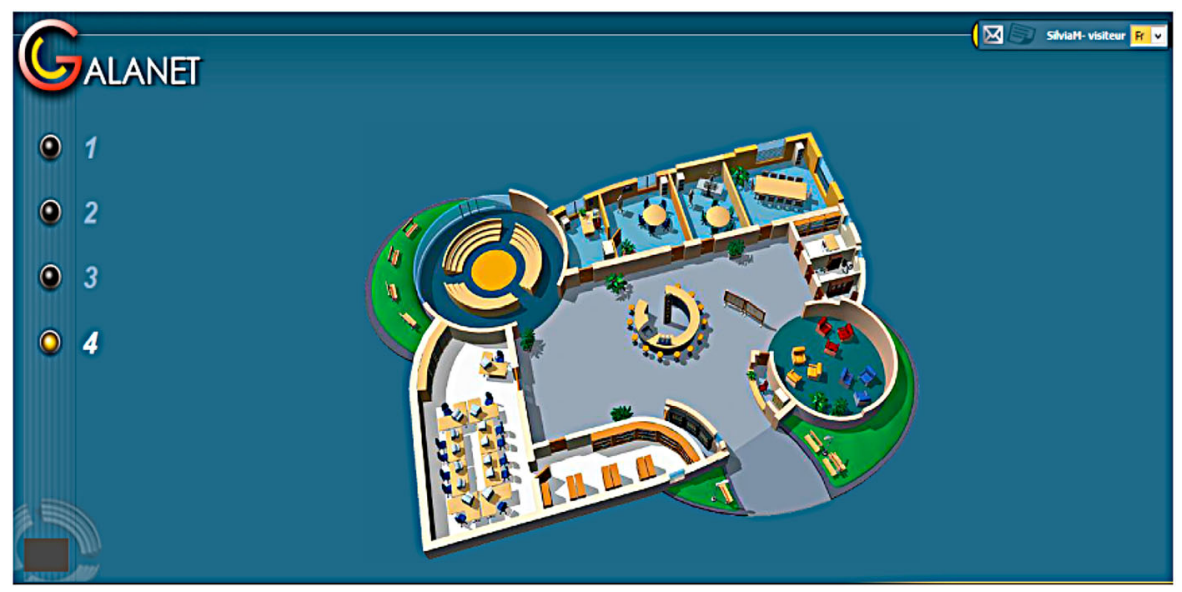

Figure 1. Homepage of the Galanet Platform (now deactivated).

top left side of the plan); (b) e-mail in the personal bureau (next to the discussion forums); (c) 3 chat rooms (in the bottom right side).

An intercomprehension 'session' in Galanet, i.e. from the beginning to end of the collaborative and plurilingual project, follows a chronological path in four stages (cf. Araújo e Sá, de Carlo, and MeloPfeifer 2010, 282; see also Melo-Pfeifer 2015), visible on the left side of the platform (see Figure 1):

i. Breaking the ice and choosing a theme: (i) participants present themselves, get to know other students' profiles and discuss about the project, their expectations and motivations; and (ii) they suggest different topics of discussion, leading them to negotiate and choose one of the themes for following collaborative work;

ii. Brainstorming: Participants discuss sub-themes in order to organize a 'press dossier';

iii. Collecting documents and debate: Participants gather, share and debate documents and web references to illustrate the different sub-theme;

iv. Elaborating and publishing the press dossier: Each team collaboratively writes synthesis of each debate, which will be integrated in the press dossier, alongside with the diverse contributions to the discussion.

As stated, the chat room communication under study could be named a 'multi-pluri' linguistic setting (Ehrhart 2010): it merges the multilingualism of the communicative contract (all RL of the

Table 1. Configuration of a multi-pluri linguistic setting (Araújo e Sá, de Carlo, and Melo-Pfeifer 2010, 284; see also Melo-Pfeifer 2015).

\begin{tabular}{llcll}
\hline Countries & \multicolumn{1}{c}{ Teams } & Number of participants & Languages of reference & 'Target' languages \\
\hline Argentina & Che, Rio Cuarto & 14 & ES, FR & FR, IT \\
Belgium & Les Montois & 8 & FR & ES, IT, PT \\
France & Les Canuts de Lyon & 9 & FR, IT, ES & FR, ES, PT \\
& Le rane di Grenoble & 19 & FR, IT, ES & FR, IT, ES \\
& RA and C Lyon 2 & 16 & FR, PT, ES & PT, ES, FR \\
& 'Les Dahuts' di Monica & 18 & FR, IT & IT, ES, FR \\
Italy & Gli spagnoli di economia & 15 & IT, FR & FR, ES \\
& Cassino - Martine & 19 & IT, FR & FR, IT \\
& Le Dino-saure,unicas2 & 14 & IT, FR, ES & FR, ES, IT \\
Portugal & Lusomaníacos & 17 & PT, FR & FR, ES, IT \\
& Os Quinas & 17 & PT, FR & FR, ES, IT \\
Spain & forum2004BCN & 34 & ES, FR & FR, ES \\
& Madrid & 36 & FR, FR & IT, PT \\
\hline
\end{tabular}


project are included) and the plurilingual competence of the participants (individual repertoires), grouped by teams/universities and linguistic profiles. All participants in the session, occurring from February to May 2004, revealed a plurilingual individual repertoire, shown in Table 1. As we mentioned previously, the 'reference language' is the RL in which the subjects feel most skilful (it could be the participant's so-called Mother Tongue or simply the RL they are most comfortable with if their Mother Tongue is a non-RL). The target $\mathrm{RL}$ are languages already learned, being learned at school/university, acquired in the host country and/or included in participants' linguistic projects.

During Canosession, 13 teams from 7 countries (Argentine, Belgium, France, Italy, Portugal and Spain) participated in the interactions (Table 1), with a significant number of participants coming from Spain (70 participants), France (62 participants) and Italy (48 participants).

The 209 students participating in this session were recruited on the basis of their attendance of language classes or foreign language teacher education modules provided by the university teachers-researchers involved in the development of the Galanet platform. The 27 teachers/researchers participated as animators/tutors. Participation was usually not made on a free and voluntary basis but integrated in the curriculum of certain academic subjects. It was made clear that the project was launching an innovative platform aiming to study the possibilities of communication among speakers of different RL. Following this premise, the communicative contract stressed that communication should occur resorting only to RL and that speakers should mainly use their reference language.

With regards to that contract, we may say that every speaker was simultaneously considered an expert speaker of (at least) one RL and non-expert speaker of the other languages. We are thus faced with conditions which provide valuable observation for moments of multilingual teaching and learning as such a communicative situation, called 'exolingual' (Noyau and Porquier 1984; see also Bange 1992), is understood by participants as a context where teaching and learning may occur due to the communicative and linguistic asymmetries and the desire to co-construct meaning. Since most participants declared two RL as reference languages and targeted multiple languages as goals for multilingual reception, we may infer that translanguaging will occur, since participants, wishing to acquire features in several languages, will actively reuse the newly acquired linguistic items.

\section{The two multilingual chat sequences: a rationale}

The two sequences we will focus on in this contribution occurred in the second intercomprehension session of Galanet (between February and May 2004). Table 2 presents the linguistic profile of all participants in the sequences, as well as their status in the session (tutor or student).

The two chat sequences (Tables 3 and 4) were selected because they are representative of the collaborative work surrounding communicative problems such as linguistic opacity. They conform to the sequences of repair described by van Lier (1988; see also Araújo e Sá and Melo 2007), as the trigger of a linguistic problem and the repair work aiming at re-establishing intercomprehension are made visible. Furthermore, regarding the theoretical standpoint of this contribution, these two sequences violate two monoglossic dispositions of the communicative contract: production in a

Table 2. Profile and status of participants in the two chat sequences (participants by order of appearance in the analysed sequences).

\begin{tabular}{lllll}
\hline Nickname & Status & Country & Reference Languages & Target Languages \\
\hline SilviaM & Tutor & Portugal & PT (FR) & FR, ES, IT \\
Djose & Tutor & Italy & ES (FR, IT) & IT, FR \\
Remy & Student & Italy & IT (FR, ES) & IT, FR, ES \\
Isadora & Student & Italy & IT (FR, ES) & IT, FR, ES \\
Lusitana & Student & Portugal & PT (FR) & FR, ES, IT \\
AntonioR & Student & Spain & ES (FR) & FR, IT, PT \\
Esmeralda & Student & Portugal & PT (FR) & FR, ES, IT \\
Colombia & Tutor & France & ES (FR) & FR, IT, PT \\
CristinaV & Student & Spain & ES (FR) & FR, IT, PT \\
\hline
\end{tabular}


Table 3. Chat sequence 1: 'voglio coger gli aereo!'

\begin{tabular}{ll}
\hline Chat sequence \# 1 & \\
\hline Original (language used in parenthesis) & \multicolumn{1}{c}{ English translation } \\
\hline [SilviaM] Como se diz avião em italiano? (PT) & [SilviaM] How do you say avião in Italian? \\
[djose] aereo (IT) & [djose] aereo \\
[djose] si te refieres a avion (IT/FR) & [djose] if you are talking about 'avion' \\
[Remy] Giusto Djosé!!!! (IT) & [Remy] Right Djosé!!!! \\
[SilviaM] voglio coger gli aereo! (IT/ES) & [SilviaM] I want to 'coger' a plane \\
[SilviaM] Quem corrige a minha frase?????? Je je je (PT) & [SilviaM] Who wants to correct my sentence?????? He he he \\
[Isadora] Cosa vuoi dire con aviao, Silvia? (IT/PT) & [Isadora] What do you mean by 'aviao', Silvia? \\
[djose] voglio prendere l'aereo (IT) & [djose] I want to catch a plane \\
[SilviaM] plane! (EN) & [SilviaM] plane! \\
[djose] silvia no ingles (IT) & [djose] silvia no English \\
[SilviaM] Gracias! Gracie mille! (ES/IT) & [SilviaM] Thank you! Thank you so much! \\
[SilviaM] Sorry :(( (EN) & [SilviaM] Sorry :(( \\
[djose] jajjajjajaj & [djose] hahhahhahah \\
\hline
\end{tabular}

reference $R L$ and use of $R L$ only. From this perspective, they can help us support the claim for a more heteroglossic approach to intercomprehension.

In the first chat sequence (see Araújo e Sá and Melo 2007 and Bono and Melo-Pfeifer 2011, for a different analytical focus on the study of this excerpt), speakers are engaged in a fictional situation: Isadora, from an Italian university, explains that she is leaving the chat because she should start cooking her meal. Since the meal she was about to cook sounded so delicious, SilviaM, a Portuguese tutor, signals her wish to join her by plane. The problem is that, she does not know how to say it in the language of the fictionalized host, thereby starting a relatively long sequence where she declares her willingness to express herself in the Italian language.

After knowledge of the word 'plane' is acquired, grammatical correctness is achieved, a monolingualised utterance is co-produced, the linguistic contract is re-established and all participants return to Isadoras' thematic path (the meal to be prepared).

In chat sequence \#2 (see Melo-Pfeifer 2015 for a complementary analysis), the participants are engaged in a specific theme of this session: telling funny stories or jokes, in particular jokes with an intercultural background. In this sequence, however, attesting to the unpredictability of conversational themes in chat rooms, they start telling jokes about blonds. After resolving the lexical opacity around the word 'blonde' (in French), students and tutors return to the subject: jokes about 'blond women'.

As we can observe, both sequences are multi-plurilingual: sequence 1 uses elements from four languages (one being a non-RL) and sequence 2 uses three RLs. In both sequences, utterances in more than one recognizable language are produced and speakers use more than just one RL or change the language of communication between utterances.

Furthermore, other semiotic sense-makers and sense-containers are also present, co-constructing meaning in this particular situation: for example, expressive punctuation is used to ask for help ('??????'), interjections are used to soften face threatening acts ('jajjajjajaj'), smileys are used to

Table 4. Chat sequence 2: 'blagues = bromas.

\begin{tabular}{ll}
\hline Chat sequence \# 2 & \\
\hline Original (language used in parenthesis) & \multicolumn{1}{c}{ English translation } \\
\hline [lusitana] c sympa les blagues de blonde (FR) & [lusitana] it's very nice, the blagues about blond women \\
[AntonioR] ¿Que son blagues? (ES, FR) & [AntonioR] What are blagues? \\
[esmeralda] blagas sao piadas, anedotas (ES, PT) & [esmeralda] blagas are jokes, anecdotes \\
{$[$ SilviaM] Blagues son anedotas ... . piadas! (FR, ES, PT) } & [SilviaM] blagues are anecdotes ... jokes \\
[colombia] blagues = bromas (FR, ES) & [colombia] blagues = jokes \\
[lusitana] blagues sao historias que fazem rir (FR, PT) & [lusitana] blagues are stories that make you laugh \\
[CristinaV] tambien pueden ser chistes (ES) & [CristinaV] they can also be tricks \\
\hline
\end{tabular}


reinforce an apology $\left({ }^{\prime}:\left(\left(^{\prime}\right)\right.\right.$ and arithmetic symbols are used to express the equivalence between two lexical items in the RL continuum ('blagues = bromas').

\subsection{Translanguaging to learn}

Both sequences presented in the previous section show the orientation 'translanguaging to learn' through participants' strong bidirectional attention, both to the meaning that is being collaboratively achieved and the form of the utterances allowing that co-construction. This strong bidirectional attention is visible in participants' high 'cooperative disposition' (Canagarajah 2014) and explicit agency, as they ask for help in cases of linguistic opacity ('What do you mean by aviao, Silvia?' and 'What is a blague?') or overtly ask for 'bits of languages' (Blommaert 2010) in order to start or complete a linguistic performance in a given language ('How do you say avião in Italian?'). Translanguaging thus becomes a means of performing multilingualistically, as we will see in the next section.

This explicit agency, i.e. active and strategic linguistic behaviour, is closely related to participants wish to get involved in a potential language learning act, as the multilingual context is perceived as linguistically rich and learner-friendly. The 'just-in-time' learning provided by constant feedback from other participants, seen by their interlocutors as language experts, helps to create this sense of translanguaging as a secure and natural means of improving the learning potential offered by the communicative situation. The perception of this secure and comfortable environment is visible through the use of smileys, repeated punctuation and use of onomatopoeias and other signs of friendliness (such as play and humour, as in 'voglio coger gli aereo! / I want to "'coger" a plane'). As we observed, students work together to solve linguistic problems, through language-related episodes which are clearly focused on form ('Quem corrige a minha frase?????? Je je je /Who wants to correct my sentence?????? He he he'), but which are meaningful for the purposes of the ongoing communication. Multilingual chat rooms then could be called 'spatial repertoires' (Pennycook and Otsuji 2015) because overlapped words and utterances and their combination with non-verbal signs only make sense when combined with the affordances of the virtual place where they take place. So, the virtual space is understood as a niche where articulated moments, resources and tasks merge, connecting the participants and providing a framework to learn. From this perspective, the virtual chat 'space' is not only the context or the technological means by which the communication takes place but also a shared resource conveying meaning, both embodying translanguaging and actively participating in its semiotic construction.

Both episodes further illustrate the development of distributed cognition (Brassac 1997) and the co-construction of multilingual metalinguistic awareness (Oliveira and Ançã 2009; Pinho and Andrade 2009). On the one hand, they show how 'languages can go back and forth symbiotically as mediational tools and objects of analysis within the same interaction' (Martín-Beltrás, quoted by García and Wei 2014,61). On the other hand, we can observe that one-to-one correspondences between lexical items are challenged, as the participants usually question those equivalents or provide further synonyms or paraphrases: 'if you are talking about avion' and 'they can also be tricks' (our emphasis) are good examples of how different affordances in different languages induce a higher degree of attention on linguistic phenomena. Indeed, through translanguaging, participants show and develop a stronger consciousness of matches and mismatches between different items of the linguistic repertoires being shared.

The high levels of commitment, agency and collaborative disposition of the participants, alongside the perception of this multilingual setting as an opportunity for multilingual learning, which is indeed the context of the interactions, explains the affordance chains and the (just-in-time) scaffolding cascade displayed in both sequences. In the second sequence, for example, the linguistic problem of a single participant ('What is a blague?') is addressed in turn by five participants, who provide scaffolding in three different languages (French, Portuguese and Spanish), accompanied by non-linguistic cues. Consequently, translanguaging becomes an effective way of learning and inducing learning in multilingual chat rooms: sharing linguistic problems prompts the mobilization of several participants, 
the emergence of affordances and scaffolding in several languages, accompanied by other noteworthy meaning-makers that enable subjects to pick up and use the ones that are most significant for them according to their specific profile.

\subsection{Learning to translanguage}

As we observed in the previous section, translanguaging becomes a means of performing multilingually, as this performance depends on the multilingual repertoires already acquired, as well as on those being acquired in the hic et nunc of the multilingual interaction. Thus, the ongoing learning process allows the immediate reuse of the new semiotic resources in this specific multilingual situation. This idea of performance is closely related to the idea that languages are not merely systems, but instruments of indexicality that ascribe to us an auto- or hetero-perceived identity. This perception of one's being ascribed a multilingual identity is forged, in our sequences, by translanguaging. Learning to translanguage allows the participants to publicly perform and claim a multilingual identity and be recognized as 'authentic' multilinguals.

In this sense, we could say that translanguaging, as a communicative tool to perform multilingually, has an emotional, a cognitive and a social goal. From an emotional perspective, translanguaging allows each participant to address Others in their languages, which has a strong affective connotation and is perceived as an affective response to other multilingual subjects taking part in the conversation. It further allows playing with one's own repertoires, to share and enlarge them, and challenge the constraints of the pre-given contract, both through linguistic ('Plane', 'Gracias! Gracie mille!') and non-linguistic resources ('Sorry :((' and 'jajjajjajaj'). From a cognitive perspective, translanguaging allows the multilingual subject to present themselves as a 'life-long' learner, as each newly learnt linguistic item can be immediately reused in forthcoming communicative events. This affective and cognitive dimension of 'learning to translanguage' can only be performed because all participants see each other as multilingual partners with multilingual competences, able to interpret and negotiate the meaning of translanguaging acts, i.e. as competent social actors.

The episodes we have analysed make clear that different languages are used to mediate social interaction ('Cosa vuoi dire con aviao, Silvia?'), to reinforce the presence of the Other by simultaneously addressing multiple affordance providers ('Gracias! Gracie mille!'), to increase understanding in case of communicative clashes ('blagues =bromas') and to increase opportunities for multilingual production ('voglio coger gli aereo!').

Thus, through translanguaging, speakers acknowledge languages and bits of language as communicative tools, embedded in the practices they are used in and according to personal needs in collective endeavours.

\section{Synthesis and perspectives}

Through the analysis of our chat room multilingual interactions, we could observe a double orientation towards translanguaging. On the one hand, translanguaging was used by participants to learn some aspects of the other RL present in the platform (normally lexical items), through the co-production of multiple affordance and scaffolding chains in the multilingual and multi-participant environment. In multilingual interaction, and depending on individual and collective agency, 'languages may be mediational tools to develop each other' (Pennycook 2010, 131), i.e. linguistic resources available to speakers are collaboratively used and called upon to contribute to the development of further linguistic resources, that in turn will be mutualized and reinvested. On the other hand, learning other 'bits of language' allowed students to translanguage, to perform a multilingual self and to co-construct meaning in a much more efficient and meaningful way, fostering multilingual socialization, affective bonds, cooperative disposition, creativity and play and humour. To sum up, translanguaging becomes a strategy of scaffolding the RL being used to communicate, becoming 
therefore a strategic competence to develop one's own multilingual discourses and engage in multilingual communication. Translanguaging is thus a creative communicative process and an engaging learning strategy, 'that is the property of the agents' way of acting in interactions, rather than belonging to the language system itself' (García and Wei 2014, 25).

The communicative contract of the Galanet platform is defined as multilingual, stressing that each student should use an RL and understand the RL of the other interlocutors. However, because students are plurilingual, they do not abide by this quite restrictive communicative contract; and use their full linguistic repertoires (RLs and non-RLs). Indeed, intercomprehension is not just the 'taking in' and 'producing of' linguistic forms in specific languages, as the monoglossic receptionproduction relationship underpinning this specific theoretical framework usually puts it. Rather, it is the constant reconfiguration of (speakers') semiotic resources, according to the available affordances, in order to collaboratively achieve meaning and adapt their communicative verbal, nonverbal and para-verbal behaviour. Our analysis made clear that, even if monoglossic linguistic norms were not totally forgotten (as students consciously demanded or provided specific knowledge in specific languages, or asked for 'monolingualisation'), speakers privileged social activity over language structures. Here again, Galanet provides excellent conditions to observe moments of multilingual teaching and learning, an example of what has been called 'exolingual' (Noyau and Porquier 1984) because of the different knowledge and skills each participant mobilizes within the interaction. Such a communicative situation is understood by participants as a context where teaching and learning may occur, because of the linguistic and communicative asymmetries and the desire to co-construct meaning.

Thus, our conclusions lead us to support a more heteroglossic perspective of intercomprehension between RL, in order to: (i) understand the complex use of multilayered and intersected semiotic resources; and (ii) avoid essentializing intercomprehension as an alternate and juxtaposed use of languages belonging to the same linguistic family (following Melo-Pfeifer 2015). This led us to define intercomprehension between RL as acts of 'multi-plurilingual' performance. Furthermore, translanguaging in these multilingual written online conversations is plurisemiotic, as it integrates multiple languages and semiotic resources: $\mathrm{RL}$, other 'bits of language', other sense-makers and sense-containers (smileys or the expressive use of punctuation and capital letters).

Finally, it was possible to observe the strategic use of translanguaging skills (with specifically social, affective and cognitive goals), together with the subjects' explicit agency when engaged in a complex and multilingual communicative scenario. Translanguaging, we argued, is a situated act leading to the development of multilingual performance.

In terms of linguistic education at school, we agree with García, Flores, and Woodley when they state that 'it is important for schools to create transglossic spaces where students' multiple language practices in interrelationship can produce integrated knowledge, deep understandings, and coherent identifications and performances as bilinguals [or multilinguals]' $(2012,48)$. It would also be empowering to speak to students about issues such as 'translanguaging', 'multilingual communication' and 'intercomprehension' because, as Lo Bianco puts it, 'as concepts are named and distinguished we can then proceed to deepen, enrich, problematize and debate our social lives more fully' $(2014, x v)$. This is precisely what language education and 'linguistic action' should be about, and linguistic educative scenarios such as the one proposed by Galanet and other projects on intercomprehension could indeed start the discussion.

\section{Notes}

1. GALANET (plateforme pour le développement de l'intercompréhension en Langues Romanes) was a Socrates/Lingua Project, coordinated by Christian Degache of Université Stendhal, Grenoble 3 (France), which included six other institutions: Universidade de Aveiro (Portugal), Universitat Autònoma de Barcelona (Spain), Universidad 
Complutense de Madrid (Spain), Università de Cassino (Italy), Université Lumière Lyon 2 (France), and Université de Mons-Hainault (Belgium). For further information and access to team publications, please visit www.galanet. eu.

2. The session studied in this contribution was object of different analysis in previous publications, including Araújo e Sá, de Carlo, and Melo-Pfeifer (2010), Araújo e Sá and Melo (2007), Bono and Melo-Pfeifer (2011) and MeloPfeifer (2014, 2015 and 2016).

\section{Disclosure statement}

No potential conflict of interest was reported by the authors.

\section{Funding}

This work was supported by Fundação para a Ciência e a Tecnologia: [Grant Number PEst-C/CED/UI0194/2013].

\section{Notes on contributors}

Sílvia Melo-Pfeifer is Associate Professor for Foreign Language Education (French and Spanish) at the University of Hamburg (Germany). Her research interests focus on pluralistic approaches to languages and cultures, plurilingual interaction and heritage language education.

Maria Helena de Araújo e Sá is Full Professor for Foreign Language Education at the University of Aveiro (Portugal). Her research interests focus on Intercomprehension between Romance Languages, teacher education and intercultural education and research. She is the Director of the Research Centre on Didactics and Technology in the Education of Trainers CIDTFF.

\section{References}

Araújo e Sá, M. H. 1996. “Processos de interacção verbal em aula de Francês Língua Estrangeira: contributos para o estudo das actividades dialógicas de adaptação verbal" [Verbal Interaction Processes in French as Foreign Language: Contributions to the Study of Dialogical Activity of Verbal Adaptation]. Doctoral Diss., Universidade de Aveiro, Aveiro.

Araújo e Sá, M. H, M. de Carlo, and S. Melo-Pfeifer. 2010. "'O que diriam sobre os portugueses?????': Intercultural Curiosity in Multilingual Chat-Rooms." Language and Intercultural Communication 10 (4): 277-298.

Araújo e Sá, M. H, and S. Melo. 2003. “'Beso em português diz-se beijo : *': la gestion des problèmes de l'interaction dans des chats plurilingues romanophones" [Management of Interaction Problems in Plurilingual Romanophone Chats]. LIDIL 28: 95-108.

Araújo e Sá, M. H, and S. Melo. 2007. "On-line Plurilingual Interaction in the Development of Language Awareness." Language Awareness 16 (1): 7-14.

Araújo e Sá, M. H., and S. Melo-Pfeifer. 2010. Formação de Formadores para a Intercompreensão: princípios, práticas e reptos [Training Trainers for Intercomprehension: Principles, Practices and Challenges]. Aveiro: Universidade de Aveiro.

Aronin, L., and D. Singleton. 2008. "Multilingualism as a New Linguistic Dispensation." International Journal of Multilingualism 5 (1): 1-16.

Aronin, L., and D. Singleton. 2012. Multilingualism. Amsterdam: John Benjamins Publishing Company.

Bailey, B. 2011. "Heteroglossia." In The Routledge Handbook of Multilingualism, edited by M. Martin-Jones, A. Blackledge, and A. Creese, 439-453. Oxon: Routledge.

Bange, P. 1992. "À propos de la communication et de l'apprentissage de L2 (notamment dans ses formes institutionnelles)" [About Communication in and Learning a L2 - Particularly in its Institutional Forms]. Acquisition et interaction en langue étrangère 1: 53-85.

Bär, M. 2009. Förderung von Mehrsprachigkeit und Lernkompetenz. Fallstudien zu Interkomprehensionsunterricht mit Schülern der Klassen 8 bis 10 [Developing Multilingualism and Learning Skills. A Case Study About Intercomprehension Classes in Grades 8-11]. Tübingen: Narr.

Blackledge, A., and A. Creese. 2014. "Heteroglossia as Practice and Pedagogy." In Heteroglossia as Practice and Pedagogy, edited by A. Blackledge, and A. Creese, 1-20. London: Springer.

Blommaert, J. 2010. The Sociolinguistics of Globalization. Cambridge: Cambridge University Press.

Bono, M., and S. Melo-Pfeifer. 2011. "Language Negotiation in Multilingual Learning Environments." International Journal of Bilingualism 15 (3): 291-309.

Brassac, C. 1997. "Processus cognitifs en situation d'interaction. De la communication à la communiaction" [Cognitive Processes in Interaction Situations. From Communication to Communication]. In Le mouvement: des boucles sensori-motrices aux représentations cognitives et langagières, Actes de la Sixième École d'été de l'Association 
pour la recherche cognitive, Juillet 1997. Accessed August 2004. http://www.arco.asso.fr/downloads/Archives/Ec/ BRASSAC.pdf.

Braunmüller, K., and L. Zeevaert. 2001. Semikommunikation, rezeptive Mehrsprachigkeit und verwandte Phänomene. Eine bibliographische Bestandsaufnahme [Semi Communication, Receptive Multilingualism and Related Phenomena. A Bibliographic State of the Art]. Hamburg: SFB 538 (Working Papers in Multilingualism, B/19).

Canagarajah, S. 2011. "Codemeshing in Academic Writing: Identifying Teachable Strategies of Translanguaging." The Modern Language Journal 95 (iii): 401-417.

Canagarajah, S. 2013. Translingual Practice. Global Englishes and Cosmopolitan Relations. Oxon: Routledge.

Canagarajah, S. 2014. "Theorizing a Competence for Translingual Practice at the Contact Zone." In The Multilingual Turn. Implications for SLA, TESOL and Bilingual Education, edited by S. May, 78-102. Oxon: Routledge.

Candelier, M., A. Camilleri-Grima, V. Castellotti, J.-F. de Pietro, I. Lőrincz, F.J. Meißner, A. Noguerol, A. Schröder-Sura and M. Molinié. 2012. A Framework of Reference for Pluralistic Approaches to Languages and Cultures. Competences and Resources. Graz: European Centre for Modern Languages / Council of Europe. http://www.ecml.at/tabid/277/ PublicationID/82/Default.aspx.

Capucho, M. F. 2011. "Cooperating and Innovating - Redinter, Working Together for the Implementation of Intercomprehension Methodologies." In International Conference 'The Future of Education', edited by Pixel. http:// www.pixel-online.net/edu_future/conferenceproceedings.php.

Capucho, M. F. 2012. "L'Intercompréhension - un nouvel atout dans le monde professionnel" [Intercomprehension - A New Trump in Professional Contexts]. In Actes du colloque IC2012. Intercompréhension : compétences plurielles, corpus, intégration, edited by Ch. Degache and S. Garbarino. http://ic2012.u-grenoble3.fr/OpenConf/papers/67.pdf (s/ISBN).

Carpi, E., and M. De Carlo. 2009. "L'impatto del mezzo informatico nella costruzione delle strategie di gestione dei conflitti" [The Impact of the Electronic Communicative Means in the Construction of Strategies of Conflict Management]." In A Intercompreensão em Línguas Românicas. Conceitos, Práticas, Formação, edited by M. H. Araújo e Sá, 151-164. Aveiro: Universidade de Aveiro.

Creese, A., and A. Blackledge. 2010. "Translanguaging in the Bilingual Classroom: A Pedagogy for Learning and Teaching?" The Modern Language Journal 94 (1): 103-115.

Crystal, D. 2011. Internet Linguistics. London: Routledge.

Degache, Ch. 2006. Didactique du plurilinguisme. Travaux sur l'intercompréhension et l'utilisation des technologies pour I'apprentissage des langues [Multilingual Education. Literature Review on Intercomprehension and Usage of Technologies in Language Learning]. Habilitation à diriger des recherches, université Stendhal - Grenoble 3.

Doyé, P. 2005. Intercomprehension - Guide for the Development of Language Education Policies in Europe: From Linguistic Diversity to Plurilingual Education. Reference Study. Strasbourg: Council of Europe.

Doyé, P., and F.-J. Meissner, eds. 2010. Lernerautonomie durch Interkomprehension: Projekte und Perspektiven / L'autonomisation de l'apprenant par l'intercompréhension: projets et perspectives [Promoting Learner Autonomy Through Intercomprehension: Projects and Perspectives]. Tübingen: Narr.

Ehrhart, S. 2010. "Pourquoi intégrer la diversité linguistique et culturelle dans la formation des enseignants au Luxembourg?" [Why Should Linguistic and Cultural Diversité be Integrated in Teacher Education in Luxembourg?]. In Plurilinguisme et formation des enseignants : une approche critique, edited by S. Ehrhart, C. Hélot, and A. le Nevez, 221-237. Frankfurt am Main: Peter Lang.

Gajo, L., and L. Mondada. 2000. Interactions et acquisitions en contexte [Interactions and Acquisitions in Context]. Fribourg: Editions Universitaires Fribourg Suisse.

García, O. 2014. "Countering the Dual: Transglossia, Dynamic Bilingualism and Translanguaging in Education." In The Global-Local Interface, Language Choice and Hybridity, edited by R. Rubdy, and L. Alsagoff, 100-118. Bristol: Multilingual Matters.

García, O., N. Flores, N., and H. Woodley. 2012. "Transgressing Monolingualism and Bilingual Dualities: Translanguaging Pedagogies." In Harnessing Linguistic Variation to Improve Education, edited by A. Yiakoumetti, 45-75. Bern: Peter Lang.

García, O., and C. Leiva. 2014. "Theorizing and Enacting Translanguaging for Social Justice." In Heteroglossia as Practice and Pedagogy, edited by A. Blackledge, and A. Creese, 199-216. London: Springer.

García, O., and L. Wei. 2014. Translanguaging. Language, Bilingualism and Education. Hampshire: Palgrave MacMillan.

Hornberger, N., and H. Link. 2012. “Translanguaging in Today's Classrooms: A Biliteracy Lens." Theory Into Practice 51 (4): 239-247.

Jewitt, C. 2009. "An Introduction to Multimodality." In The Routledge Handbook of Multimodal Analysis, edited by C. Jewitt, 14-27. London: Routledge.

Lewis, G., B. Jones, and C. Baker. 2012. "Translanguaging: Origins and Development from School to Street and Beyond." Educational Research and Evaluation 18 (7): 641-654.

Lo Bianco, J. 2014. "Foreword. Naturalising the Multilingual Turn." In The Multilingual Turn in Languages Education. Opportunities and Challenges, edited by J. Conteh, and G. Meier, xv-xvi. Bristol, MA: Multilingual Matters.

Lüdi, G. 2003. "Code-switching and Unbalanced Bilingualism." In Bilingualism: Beyond Basic Principles. Festschrift in Honour of Hugo Baetens Beardsmore, edited by J.-M. Dewaele, A. Housen, and L. Wei, 174-188. Clevedon: Multilingual Matters.

Lüdi, G. 2007. "The Swiss Model of Plurilingual Communication." In Receptive Multilingualism. Linguistic Analyses, Language Policies and Didactic Concepts, edited by J. Ten Thije, and L. Zeevaert, 159-178. Amsterdam: John Benjamins. 
Lüdi, G., K. Höchle, and P. Yanaprasart. 2013. "Multilingualism and Diversity Management in Companies in the Upper Rhine Region." In Exploring the Dynamics of Multilingualism, edited by A.-C. Berthoud, F. Grin, and G. Lüdi, 59-82. Amsterdam: John Benjamins.

Lüdi, G., and B. Py. 1986. Etre bilingue [Being a Biligual]. Bern: Peter Lang.

Matthey, M. 1996. Apprentissage d'une langue et interaction verbale [Language Learning and Verbal Interaction]. Paris: Peter Lang.

Meißner, F.-J. 2004. "Transfer und Transferieren. Anleitungen zum Interkomprehensionsunterricht" [Transfer and to Transfer. Guidelines for Lessons on Intercomprehension]. In Neuere Forschungen zur Europäischen Interkomprehension, edited by H. Klein, and D. Rutke, 39-66. Aachen: Shaker.

Melo-Pfeifer, S. 2014. "Intercomprehension Between Romance Languages and the Role of English: A Study of Multilingual Chat Rooms." International Journal of Multilingualism 11 (1): 120-137.

Melo-Pfeifer, S. 2015. "An Interactional Perspective on Intercomprehension Between Romance Languages: Translanguaging in Multilingual Chatrooms." Fremdsprachen Lehren und Lernen. Zur Theorie und Praxis des Sprachunterrichts an Hochschulen 44 (2): 100-113.

Melo-Pfeifer, S. 2016. "Translanguaging in Multilingual Chat Interaction: Opportunities for Intercomprehension Between Romance Languages." In Handbook of Research on Foreign Language Education in the Digital Age, edited by C. Wang, and L. Winstead, 189-208. Hershey , PA: IGI Global.

Noyau, C., and R. Porquier. 1984. Communiquer dans la langue de l'autre. Saint-Denis: Presses Universitaires de Vincennes.

Oliveira, A. L., and M. H. Ançã. 2009. "'I Speak Five Languages': Fostering Plurilingual Competence Through Language Awareness." Language Awareness 18 (3): 403-421.

Palmer, D., R. Martínez, S. Mateus, and K. Henderson. 2014. "Reframing the Debate on Language Separation: Toward a Vision for Translanguaging Pedagogies in the Dual Language Classroom." The Modern Language Journal 98 (3): 757-772.

Pennycook, A. 2010. Language as a Local Practice. London: Routledge.

Pennycook, A., and E. Otsuji. 2015. Metrolingualism. Language in the City. Oxon: Routledge.

Pinho, A. S., and A. A. Andrade. 2009. "Plurilingual Awareness and Intercomprehension in the Professional Knowledge and Identity Development of Language Student Teachers." International Journal of Multilingualism 6 (3): 313-329.

Porquier, R. 1994. "Communication exolingue et contextes d'appropriation: le continuum acquisition/apprentissage" [Exolingual communication and appropriation contexts: the acquisition/learning continuum]. Bulletin suisse de linguistique appliquée 59: 159-169.

Ten Thije, J. 2013. "Lingua Receptiva (LaRa)." International Journal of Multilingualism 10 (2): 137-139.

Ten Thije, J. 2014. "The Effectiveness of Lingua Receptiva (LaRa) in Multilingual Communication - Editorial." Applied Linguistics Review 5 (1): 125-129.

Ten Thije, J., and L. Zeevaert, eds. 2007. Receptive Multilingualism. Linguistic Analyses, Language Policies and Didactic Concepts. Amsterdam: John Benjamins.

van Lier, L. 1988. The Classroom and the Language Learner. New York: Longman.

Vasseur, M.-T. 2005. Rencontres de langues. Question(s) d'interaction [Language Encounters. A Question of Interaction]. Paris: Didier.

Vela Delfa, C. 2009. "La gestión de los malentendidos en los intercambios plurilingües" [The Management of Misunderstanding in Multilingual Interaction]. In A Intercompreensão em Línguas Românicas. Conceitos, Práticas, Formação, edited by M. H. Araújo e Sá, 165-176. Aveiro: Universidade de Aveiro. 